\title{
Cyber Safety of Children in the Association of Southeast Asian Nations (ASEAN) Region: a Critical Review of Legal Frameworks and Policy Implications
}

\section{Mubarak Rahamathulla ${ }^{1}$}

Accepted: 15 August 2021 / Published online: 14 October 2021

(c) The Author(s), under exclusive licence to Springer Nature Switzerland AG 2021

\begin{abstract}
The present study aimed to critically review the legal frameworks on cyber safety of children living in the member countries of the Association of Southeast Asian Nations (ASEAN) and related policy implications. Data for the present research were collected from secondary sources. The results revealed numerous inconsistencies among the ASEAN countries in legislation pertaining to the online safety of children. The present study argues that these inconsistencies could be used by criminals to easily exploit children. The study identified loopholes in legislation on age of consent, possession of child pornography, cyber bullying and sexual grooming of children. Indonesia, Laos, Malaysia, Myanmar, Singapore and Vietnam have no clear definition of the term child pornography, which means it may be possible for criminals to evade conviction for production, possession and distribution of child pornography. Legislation in Cambodia, Laos, Malaysia, Myanmar and Vietnam does not prohibit an individual from possessing child pornography. Only three ASEAN nations have a legal framework regarding child grooming for sexual purposes, while only two have policies regarding cyberbullying, and just three ASEAN nations have a formal global alliance with international law enforcement initiatives. Based on these findings, the study argues that the legal inconsistencies among ASEAN nations might result in cross-border sexual abuse and exploitation of children. Accordingly, it is suggested that countries in the ASEAN region need to urgently identify these legal inconsistencies and collaborate to improve the safety of their children in cyberspace.
\end{abstract}

Keywords Cyber safety $\cdot$ Legal framework · Policies $\cdot$ ASEAN $\cdot$ Child abuse $\cdot$ Child exploitation $\cdot$ COVID-19

Mubarak Rahamathulla

mubarak.rahamathulla@uwa.edu.au

1 School of Allied Health, University of Western Australia, Crawley, WA 6009, Australia 


\section{Background}

The Association of Southeast Asian Nations (ASEAN) comprises of ten nations: Brunei, Cambodia, Indonesia, Laos, Malaysia, Myanmar, the Philippines, Singapore, Thailand and Vietnam, located in the Southeast Asian part of the world. This regional cooperative initiative was formed in 1967 with the aim of accelerating economic growth, social progress and cultural development in the region through equality and partnership in order to strengthen the foundation for a prosperous and peaceful community of Southeast Asian Nations (ASEAN University network, 2021). The association has established dialogue and partnerships with Australia, Canada, China, the European Union, India, Japan, New Zealand, the Republic of Korea, Russia and the USA in order to foster constructive dialogue and consultation on political and security issues of common interest and concern and to make significant contributions to efforts towards confidence-building and preventive diplomacy in the Asia-Pacific region (ASEAN, 2021). The world's two most populous nations, China and India, are immediate neighbours of the ASEAN countries but are not members of ASEAN. These countries only hold the status of dialogue partners. However, these two leading economies of the world have a constant influence on the sociopolitical landscape of the ASEAN region, impacting the peace and prosperity of these nations (Chatterji, 2021; Izzuddin, 2020).

The ten countries located within the ASEAN region occupy 4.5 million square kilometres of land with a population of 634.5 million. The region comprises diverse population groups which are socially and culturally different, and the association includes nations with extremely disparate economic backgrounds. For example, the GDP per capita of Singapore is US\$52,962, as against Cambodia's per capita GDP of US\$1266.30 (ASEAN, 2017). The socioculturally diverse population groups within these countries make this region diverse and politically vibrant. The sociopolitical landscape of these nations is marked by ongoing regional issues that affect the stability of the region. For example, Myanmar has experienced serious and ongoing political turmoil within its territory for many years, impacting its neighbours also (Cuddy, 2021). Politically, Brunei and Thailand are still monarchies with traditional governance. Cambodia and Vietnam were involved in protracted wars, leading to cycles of poverty and famine (Doyle, 2014). Other member nations of ASEAN have evolved their own political structures with a combination of democracy and autocracy. Such vast diversity in the geo-sociopolitical background of the region might have contributed to a range of inconsistencies in policy formulation and cross-border collaboration, adding many layers of complexity to law enforcement and policing. This could be the reason for the range of transnational crime and security challenges which have been plaguing this region for a long time (UNODC, 2017). Sexual exploitation of children has long been a significant challenge for the ASEAN countries. The region has some of the world's most beautiful tourist destinations, attracting visitors from all over the world. For example, in the year 2019, approximately 51.57 million tourists visited the ASEAN region, compared to only 30 million in 2010 
(Statista, 2019). While the tourism industry improved the economic growth of the region, it has also resulted in children increasingly becoming the targets of sexual exploitation (for a definition of this and other key terms used in this research, please refer to Appendix), and there has been a longstanding concern in relation to the increase in child sexual exploitation (Refer to Appendix) in the ASEAN region (ECPAT, 2016a, b).

The recent advancements in information and communication technologies have added another layer to the complexity of law enforcement challenges in the ASEAN region. These countries rank as the most engaged mobile Internet users in the world. There were an estimated 400 million Internet users in the region (Reuters, 2021), and $90 \%$ of them connected to the Internet primarily through mobile phones (Google, Temasek \& Bain \& Company, 2019). The ease of connectivity with the Internet has created endless opportunities for ASEAN communities, particularly youth from minority, multi-ethnic and remote communities. The Internet penetration rate in the ASEAN region ranges from a very high $97.5 \%$ in Brunei to $49.4 \%$ in Laos, making the ASEAN youth among the most online engaged in the world. Except in Myanmar and Laos, all other countries in the region have an Internet penetration rate above $70 \%$ (Statista, 2021). It has been predicted that Southeast Asia's Internet economy, worth $\$ 105$ billion in the year 2021, will see further growth due to the COVID-19 shutdowns prompting more consumers to go online. Specifically, countries such as Indonesia, Malaysia, Vietnam, Singapore and the Philippines saw 40 million new Internet users (Reuters, 2021). The school closures due to COVID19 since early 2020 have resulted in an unprecedented and sudden increase in children accessing the Internet for online learning. The UNICEF (2021a, b, c) estimated that across East Asia and the Pacific region, school closures had affected over 325 million children, and this trend has contributed to an historic increase in children accessing the Internet.

The other geopolitical developments in the ASEAN region have also resulted in a significant increase in young people accessing the Internet. For example, there was a political coup in Myanmar on February 1, 2021, which prompted the netizens in this country and the ASEAN region to join the online collective of pro-democracy youth movements. These pro-democracy youth movements were inspired by the geopolitical turmoil occurring in neighbouring countries such as Hong Kong, Taiwan, Thailand and Myanmar. The rise of digital activism across Southeast Asia in the past half-decade has introduced a new trend of Millennials using social media to voice their concerns and garner sympathy for the citizens in the region. For example, the Milk and Tea Alliance is one such netizen political alliance that has gained popularity rapidly, prompting a surge in young people accessing the cyberspace in the ASEAN region (Lee, 2021). While it is difficult to estimate the number of young people involved in these netizen political alliances, in Laos alone-a country with a low Internet penetration rate-the hashtag "if Lao politics was good", which is critical about the Laotian government over corruption and inequality, had almost 400,000 posts as of October 2020, which were also tagged with \#MilkTeaAlliance (Leong, 2020).

While this unprecedented increase in the use of Internet and communication technology has empowered young people in the ASEAN region in many ways, it has 
simultaneously also increased the risk of children and young people being exposed to abuse and exploitation in cyberspace (please refer to Appendix for a definition of this term). The safety of children and young people in this region has been further affected by COVID-19 due to a rapid increase in the number of children accessing the Internet for education and entertainment purposes. However, this trend may not be specific to children in the ASEAN region alone. A similar trend seems to be common for children in other regions of the world as well. INTERPOL (2021) has reported a significant increase in child exploitation due to COVID-19 in various parts of the world. The pandemic prompted closure of schools, increasing the number of children exposed to the dangers of cyberspace. Restriction of international travel and tourism have led child exploitation perpetrators to use the Internet to reach children, with economic hardships due to lockdowns forcing children from poor socioeconomic backgrounds to engage in online prostitution, while limited access to childcare and other support services is reducing the quality of supervision of children. The National Centre for Missing and Exploited Children received 4.2 million reports of child exploitation incidents in April 2021, which was an increase of 2 million when compared to March 2020 and an increase of 3 million when compared to the figures as of April 2019 (Brewster, 2021). The Australian Federal Police reported 22,000 cases of child exploitation in Australia between July 2019 and June 2020, which was an increase of 50\% from more than a year ago and suggests that COVID-19 could have played a major role in this increase (Yi, 2021).

While there was an increase in child abuse and exploitation around the world due to the COVID-19 pandemic in general, the implications of this trend could be worse for children growing up in the regions of the world which were already poor pre-COVID-19. For example, Europol, the UK's National Crime Agency, the Swedish Policy Authority and other crime detection agencies around the world have reported a significant increase in demand for child sexual abuse and exploitation livestreams from traffickers in the Philippines, Cambodia and Thailand (Sullivan, 2020). Specifically, children living in socioeconomically depressed parts of the ASEAN region were already experiencing severe abuse and exploitation in cyberspace even before COVID-19 (Mubarak, 2015). The World Bank (2021) has predicted that East Asia and the Pacific region could see at least 11 million more people falling into poverty and missing meals, school and hospital visits. A vast majority of countries in the ASEAN region rely on tourism for a living, and these have been the worst affected economically, with heavy job losses (Beh \& Lin, 2021). Evidence has emerged suggesting that children primarily are victims of the economic downturn due to COVID-19 (Sullivan, 2020). It is time to critically analyse the extent to which child protection legislations and policy frameworks of countries in the ASEAN region are proactive enough to safeguard their children during these economically testing times. Using information collected from secondary sources, the present study critically reviewed the child cyber safety policies and legal frameworks of ASEAN countries. 


\section{Methodology}

Data for the present study were collected from secondary sources. Online library resources, international agency reports, newspaper articles and information available from other international data agencies were accessed to collect data. Child safety in cyberspace is a broad concept touching all sections of society-the individual child, families, policymakers, Internet service providers and the international community. The present study aimed to critically review the policies affecting all these layers and how they impacted the online safety of children living in the ASEAN nations.

\section{A Critical Review of Child Cyber Safety Policies and Legal Frameworks in the ASEAN Region}

The ASEAN region consists of ten nations that are diverse in their social and cultural heritage. These nations comprise a multitude of communities with rich traditions and value systems influenced by the region's long history and their diverse customs, traditions, religious beliefs, economic progress, innovation and technological sophistication (ASEAN, 2021). The ASEAN region has regions with significant economic disparity. At one end of the spectrum, the region includes developed countries such as Singapore, while at the other end are countries plagued by several decades of war, political turmoil and enduring poverty. This region has been well known for the stateless, minority, migrant and rural populations pushed into poverty, exploitation and hardships due to geopolitical factors (ECPAT International, $2016 \mathrm{a}, \mathrm{b})$. These vast variations in the geopolitical, sociocultural and economic backgrounds in the region have been at the heart of child exploitation and the cyber safety risks for children. The stark differences in the geopolitical backgrounds of countries located in close proximity in the region have created inconsistencies and loopholes in policies. Policymakers face the challenging and difficult task of bringing together regional countries with vast geopolitical internal issues collaborating to fight against crime fostered by the rapidly evolving information and communication technology revolution. These challenges are evident in the policy inconsistencies among the governments in the region. Table 1 presents a comparison of online child safety legislation of each ASEAN country, followed by a critical review of these laws.

\section{Brunei}

Brunei had a population of 441,532, of whom 430, 500 people used the Internet. Brunei had the highest Internet penetration rate of $97.5 \%$ in the ASEAN region (Internet world stats, 2021). Brunei implemented the Child Online Protection National Strategy Framework in 2015 (Abdullah and Metussin, 2016), and this framework clearly defined the term child pornography in line with the international standards and prohibited possession and distribution of child pornography. This 


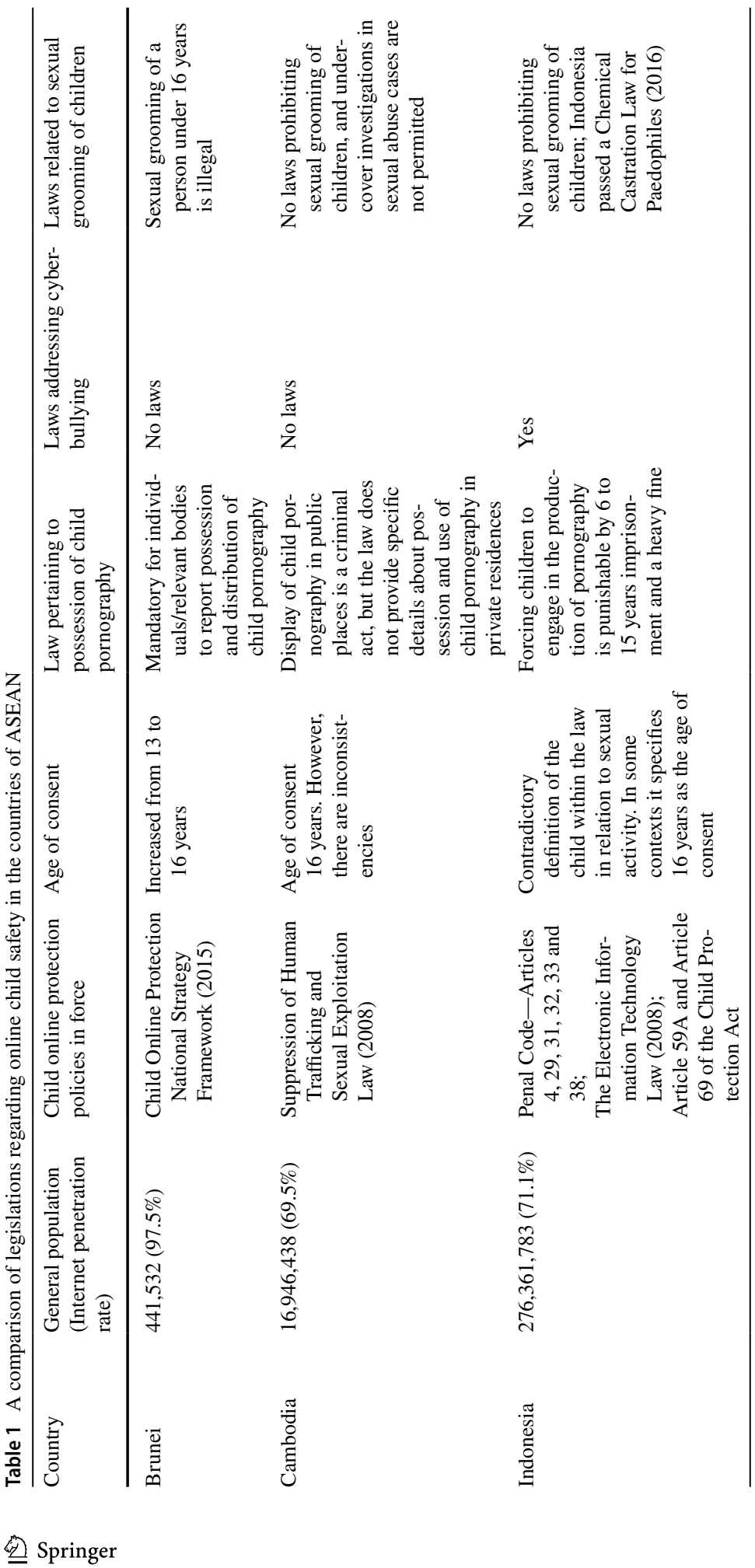




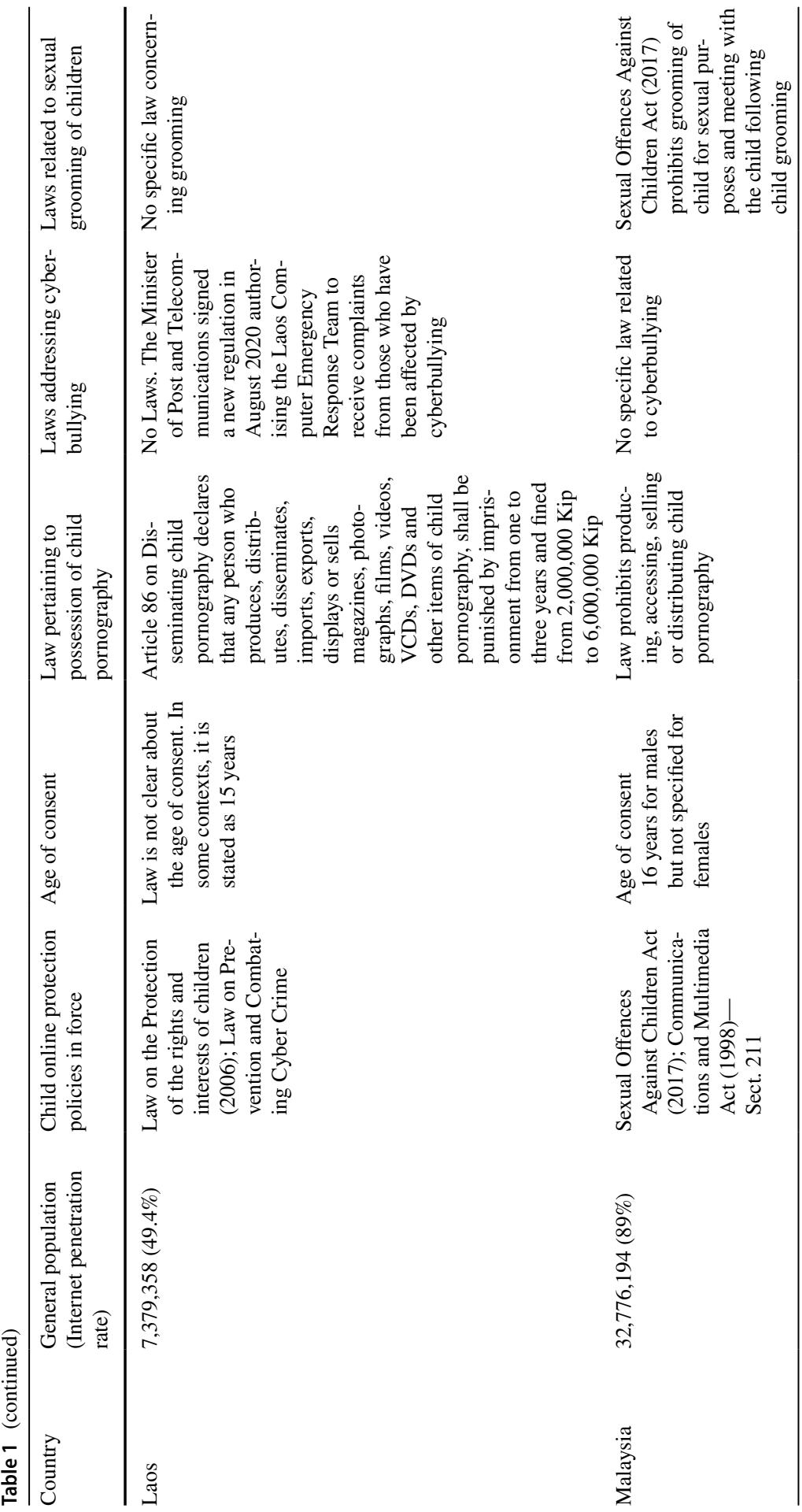




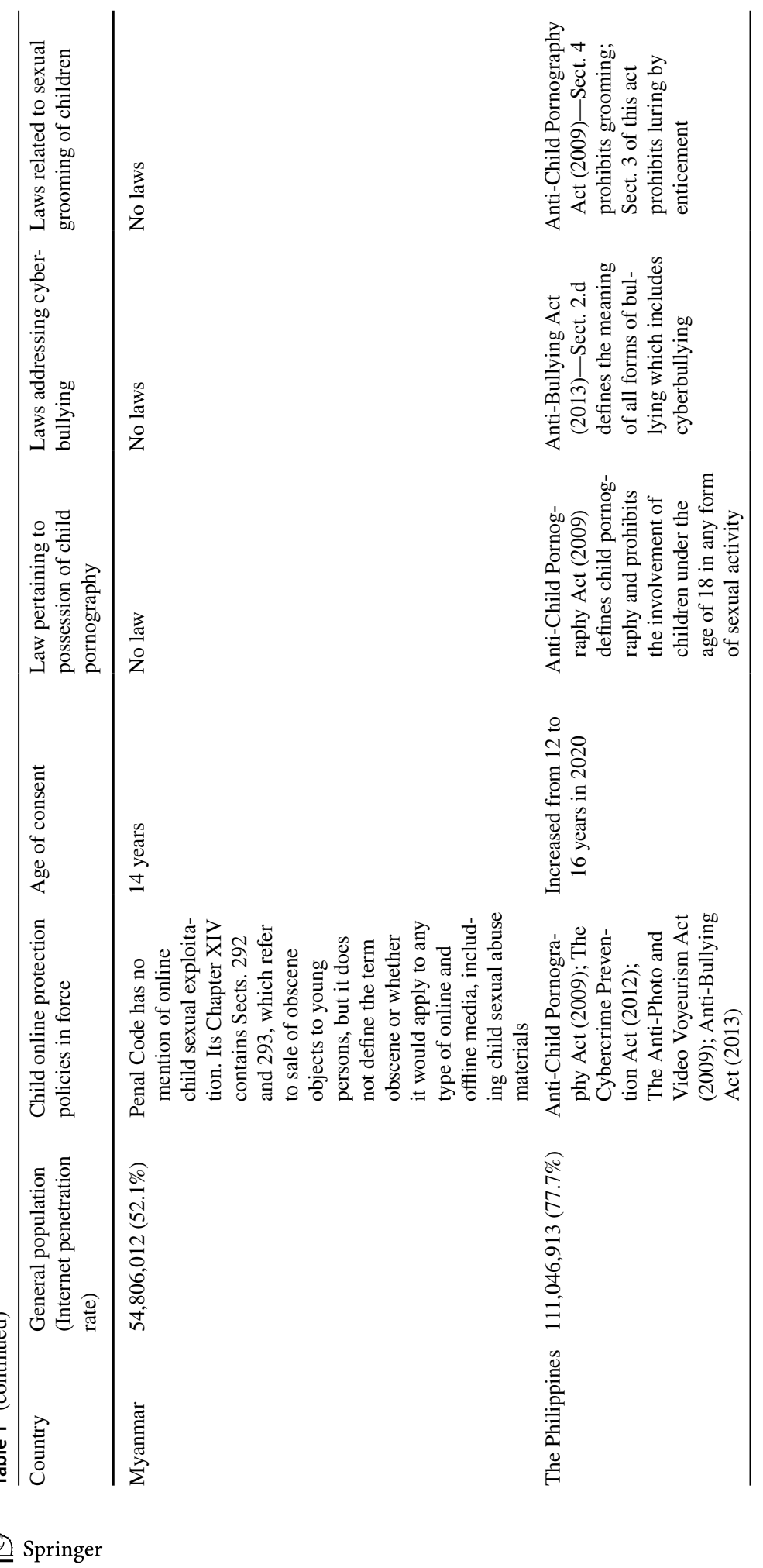




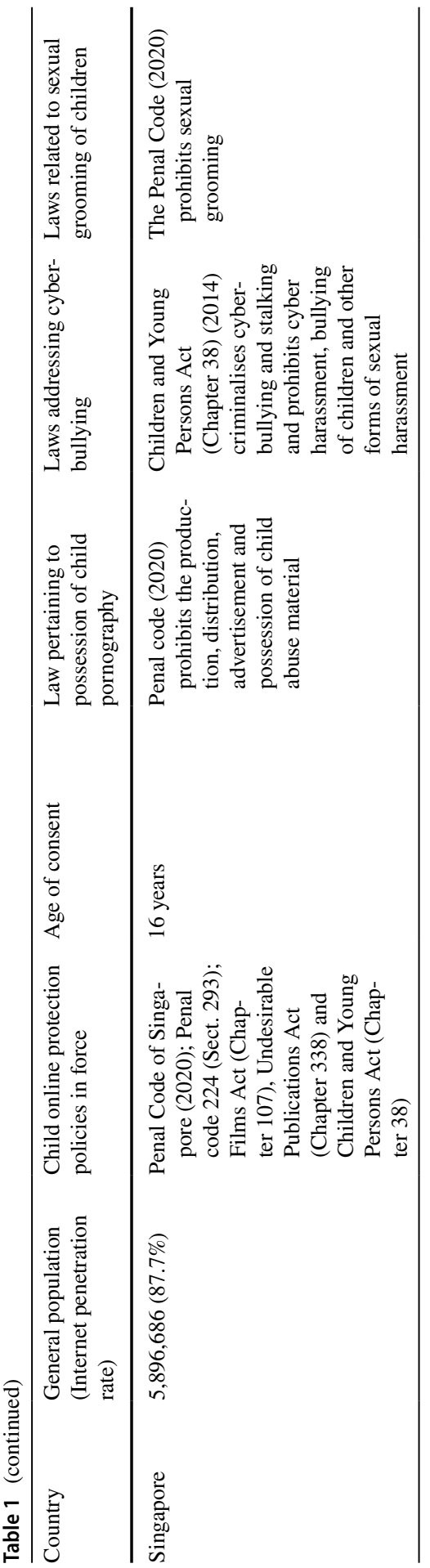




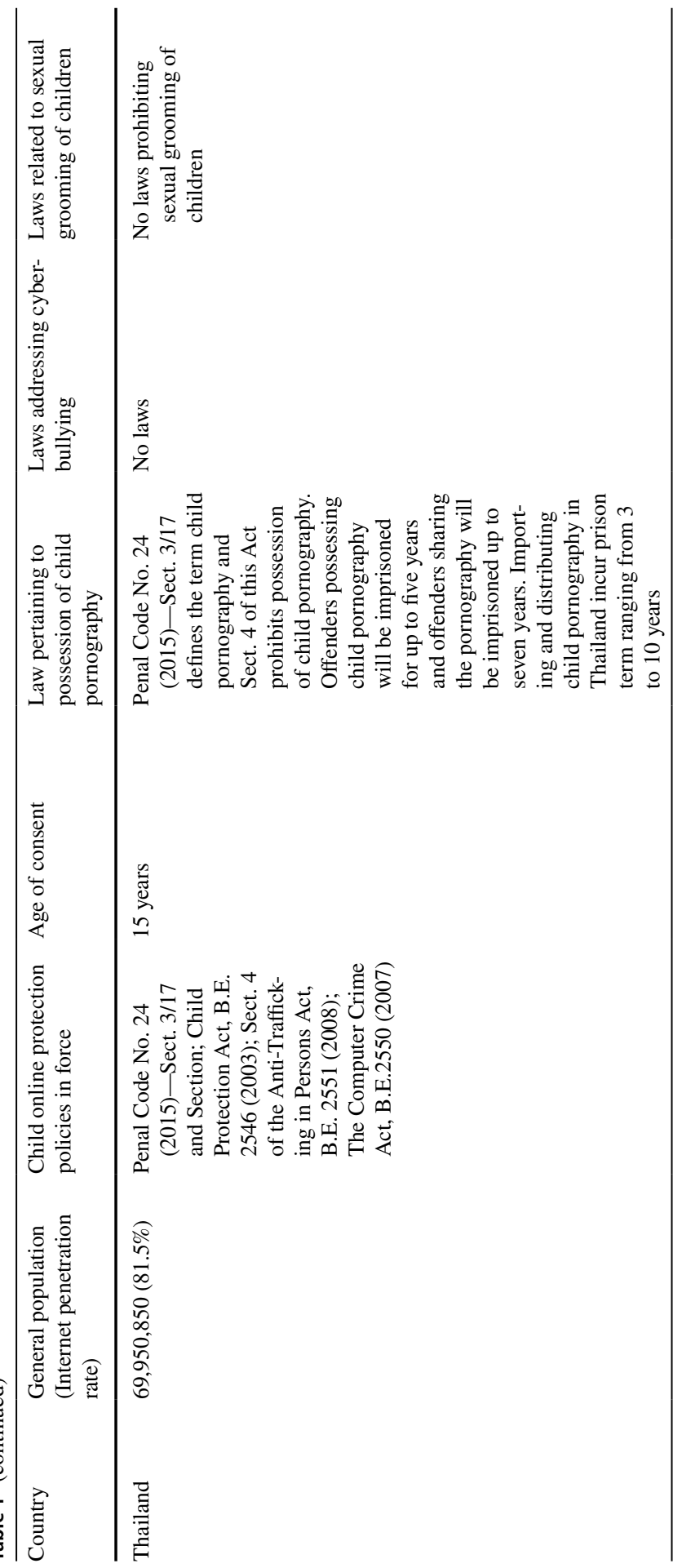




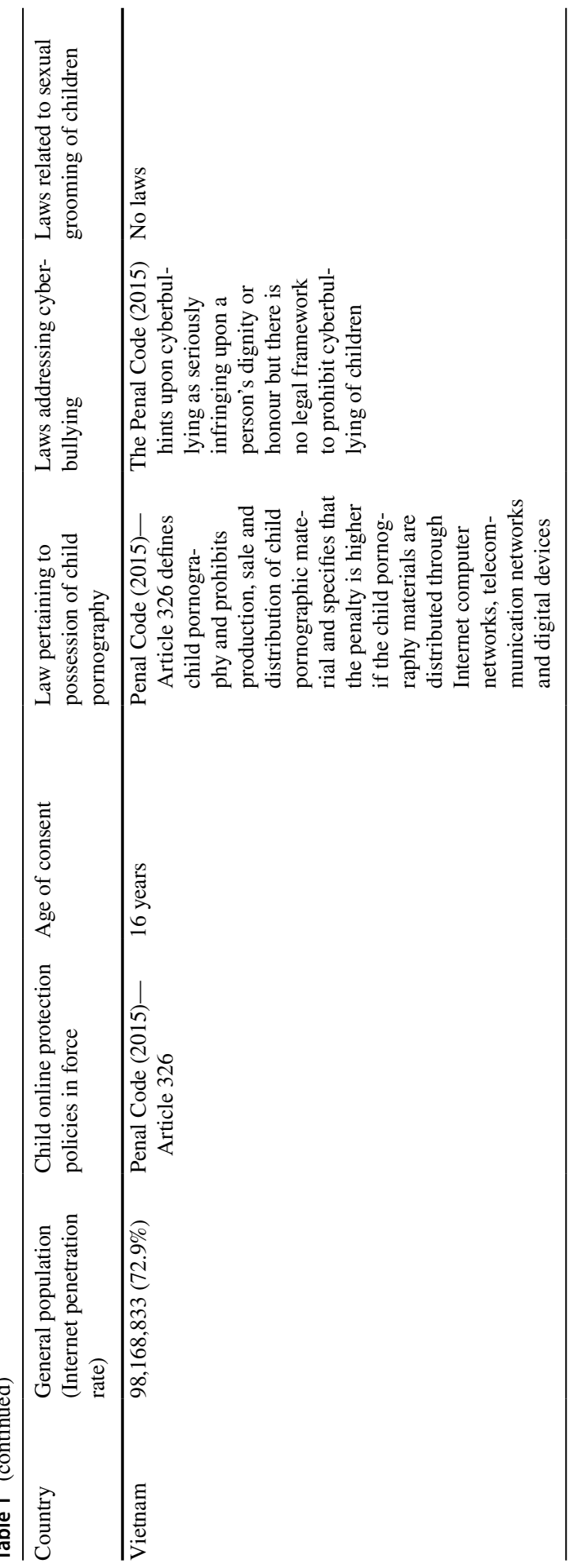


policy framework had many other child cyber safety mechanisms. For example, it made sexual grooming of a person under 16, portraying a sexual act in the presence of a person under 16 and commercial sex with a person under the age of 18 either inside or outside Brunei punishable by law. This policy framework also specified that it is mandatory for individuals and relevant bodies to report possession and distribution of child pornography. Prior to this framework, Brunei had Penal code 2001, which had legislations protecting children in general (Brunei Attorney General's Chamber, 2001), and this was amended in 2016 (Brunei Attorney General's Chamber, 2016). However, this amended version had no specific mention of cyber safety of children. Similarly, Brunei had the Children and Young Persons Order 2006 (Brunei Government, 2006), which also had no mention of the cyber safety of children. Brunei had no laws addressing cyberbullying and no legislative requirements for Internet Service Providers (ISP) to report child abuse materials to law enforcement agencies or other relevant authorities when they learn of it on their networks (Siti Khairunnisa, et al., 2013).

\section{Cambodia}

Cambodia had a population of $16,946,438$ and among this population $11,786,000$ used the Internet, indicating an internet penetration rate of $69.5 \%$ (Internet world stats, 2021). UNESCO estimated that $80.4 \%$ of Cambodian girls aged 15-24 are online, compared to $91.5 \%$ boys. The online population of Cambodia was getting younger, with $4.5 \%$ of children under 15 years of age using the Internet (Xinhuanet, 2019). Cambodia passed the Suppression of Human Trafficking and Sexual Exploitation Law in 2008 (International Labour Organisation, 2020), and this law criminalised child pornography. However, it only declared the display of child pornography in public places as a criminal act and did not prohibit possession and use of child pornography in private residences. In 2012 the Cambodian Government announced its intention to adopt Cambodia's first ever cybercrime law, and a draft was leaked in 2014, but no further details were made available (Cambodian Centre for Human Rights, 2021). Recently, the Child Protection Unit of the Cambodian Government established Internet Crimes Against Children (ICAC) — an online group to combat any form of online child sexual exploitation and abuse-but no further information had been released (Business \& Human Rights, 2021).

No laws existed regulating sex with children in Cambodia. The age of consent in Cambodia was 16 years which meant sex with a child was legal in the country and prosecution for sex with a 15-year-old child was not possible under Article 42 of the UNTAC law (1992) (Ammon, 2019). There were no laws prohibiting child abuse in cyberspace, and undercover investigations in sexual abuse cases were not permitted under Cambodian law, hindering the authorities' ability to take any disciplinary action (Blomberg, 2019). Action Pour Les Enfantes (2021) reported an increase in child exploitation and sharing of pornographic pictures of young girls via the Internet. It received information related to 30 such incidents in the first quarter of 2021. As per a recently conducted UNICEF poll and youth talk, $85.7 \%$ of young Cambodians aged between 12 and 15 were in danger of online violence, cyberbullying 
and digital harassment (The ASEAN Post, 2021). The Xinhuanet (2021) reported that Cambodia's Ministry of Post and Telecommunication's research showed 26 per cent of the Internet users in Cambodia had experienced online harassment, and the majority were children. Despite this emerging evidence, Cambodia had not legislated any laws pertaining to cyberbullying. There was no Cambodian law requiring ISPs to report material endangering child safety in cyberspace. Notwithstanding the high penetration rate of the Internet, with nearly two-thirds of the population accessing the Internet and most of them being children, Cambodia had shown little interest in safeguarding its children in cyberspace.

\section{Indonesia}

Indonesia had a population of $276,361,783$, and within this population $196,400,000$ used the Internet, showing an Internet penetration rate of $71.1 \%$ (Internet world stats, 2021). Indonesia had been proactive in passing a range of legislations to safeguard children in cyberspace. For example, its Penal Code Article 4 paragraph 1 (f) clearly defined child pornography and prohibited exposing children to pornographic materials. Articles 29, 31, 32, 33 and 38 declare producing, downloading, possessing, funding and forcing children to engage in the production of pornography as punishable by 6 to 15 years imprisonment and a heavy fine (International Centre for Missing \& Exploited Children, 2017). The Electronic Information Technology Law (2008) made cyberbullying punishable. Its Article 27 (3) mandated that anyone distributing and/or transmitting and/or accessing electronic information and/or electronic documents that insult the child is punishable by a prison sentence of 6 years and a heavy penalty. In addition, Article 59A and Article 69 of the Child Protection Act protect children from cyberbullying (Arliman et al., 2018). Wismayanti and et al. (2019), based on a systematic review of 30 research articles and 9 policy and legal documents, reported the contradictions in the definition of child in the legislations, increasing the vulnerability of children to sexual abuse, and this was especially the case for girls. Sexual grooming of children was punishable by Indonesian law, and recently Indonesia passed a chemical castration law for paedophiles in 2016 (BBC, 2016), leading medical professionals to question the ethicality of chemical castration. Indonesia had no legislation mandating ISPs to report any online material with child abuse or exploitation. Considering that it is a country with a large population and with nearly 65 million young people aged 10 to 24, comprising $28 \%$ of the population (United Nations Population Fund, 2021), Indonesia's legal and policy framework on cyber safety of children needed urgent reformation.

\section{Laos}

The Lao People's Democratic Republic had a population of 7,379,358, and of this population, 3,645,000 used the Internet, reflecting an Internet penetration rate of $49.4 \%$ (Internet world stats, 2021). Laos passed a Law on the Protection of the Rights and Interests of Children in 2006. Its Article 86 on disseminating child pornography declared that any person who produces, distributes, disseminates, imports, 
exports, displays or sells magazines, photographs, films, videos, VCDs, DVDs and other items of child pornography shall be punished by imprisonment from 1 to 3 years and fined from 2,000,000 Kip to 6,000,000 Kip (Government of Laos, 2006). However, this law was not clear about the age of consent, and it indicated the minimum age of consent as 15 years, which makes enforcement of the law on paedophiles difficult. This legal loophole in Laos and in other member nations of ASEAN with a lower age of consent had presented a major threat to the wellbeing of children. Children become easy targets for abusers and for the sex industry which could exploit children but still remain within the legal limits. Laos passed laws prohibiting the production and dissemination of pornographic content. Article 138 of the Law on Prevention and combating Cyber Crime prohibited the dissemination of pornography (ECPAT, 2017). Laos had no specific legislation on online child sexual exploitation. Laos had no specific law or legislation concerning the use of the Internet to commit crimes against children or grooming, but had enacted laws to help prevent children from accessing dangerous materials online (ECPAT, 2017). This law and no other laws in Laos obligate ISPs to report any materials present in their network with the potential of harming children. Due to an increase in cyberbullying in Laos, the Minister of Post and Telecommunications signed a new ministerial regulation in August 2020 authorising the Laos Computer Emergency Response Team to receive complaints from those who had been affected by cyberbullying (Phonevilay, 2020), but no information was available in terms of the number of children affected by cyberbullying or the number of complaints received.

\section{Malaysia}

Malaysia had a population of 32,776,194, and of this population, 29,161,765 used the Internet, with a high Internet penetration rate of $89 \%$ (Internet world stats, 2021). Malaysia passed the Sexual Offences Against Children Act in 2017 (Government of Malaysia, 2017). This act defined the meaning of child pornography and prohibited producing, accessing, selling and distributing child pornography. This Act also prohibited grooming of children for sexual purposes and meeting with the child following grooming. It made non-physical sexual assault on the child online punishable by law. While Ushama and Jalil (2020) stated that this Act had resulted in substantial reform of Malaysian law, no data pertaining to the number of convictions through this Act were available. Apart from this, Malaysia had no law in relation to cyber safety of children. The Communications and Multimedia Act 1998 (Sect. 211) prohibited indecent, obscene, false, menacing or offensive contents soliciting with the intent to annoy, abuse, threaten or harass any person, and Sect. 233 prohibited the use of network facilities or network services for commercial or non-commercial purposes (UNICEF, 2019). However, this legislation had its limitations, such as it did not criminalise possession of obscene contents and the penalties were light for any offence related to this legislation. Malaysian ISPs were not obligated to block, delete or report offensive content involving child sexual abuse and exploitation (ECPAT, 2019). Malaysia was reported to be home for 20,000 IP addresses uploading and downloading photographs and visuals of child pornography, which was the highest 
number of such IP addresses in Southeast Asia (HAKAM, 2019). While Malaysia ranked 2nd in Asia for cyberbullying among youth (Xiang, 2020), it had no specific law related to cyberbullying. With a high Internet penetration rate of $89 \%$, Malaysia has a long way to go to ensure a safe cyberspace for its children.

\section{Myanmar}

Myanmar had a population of 54,806,012, and of this population, 28,530,000 used the Internet, which is an Internet penetration rate of $52.1 \%$ (Internet world stats, 2021). Myanmar enacted its penal code, but this had no mention of online child sexual exploitation. Chapter XIV of the code contained Sects. 292 and 293, which refer to the sale of obscene objects to young persons, but it did not define the term obscene or whether this provision would apply to any type of online and offline media including child sexual abuse materials (ECPAT, 2020). Myanmar had no law prohibiting other online child abuse, and exploitative acts such as grooming, livestreaming of child sexual abuse and sexual extortion (ECPAT, 2020), which made Myanmar an unsafe country for children. Myanmar has been in serious political turmoil for a prolonged period of time and probably this could be the reason for its slow progress with policy making to protect its children in cyberspace. ISPs were not required to mandatorily report any material offending children online.

\section{The Philippines}

The Philippines had a population of $111,046,913$, and within this population, $86,300,000$ used the Internet, suggesting a high internet penetration rate of $77.7 \%$ (Internet world stats, 2021). The Philippines has been proactive in formulating legal safeguards for children in cyberspace. The country passed the Anti-Child Pornography Act 2009, which clearly defined child pornography and prohibited the involvement of children under the age of 18 in any form of sexual activity (Lawphil, 2009). Section 4 of this Act prohibited grooming, Sect. 3 of this act prohibited luring by enticement and Sect. 9 mandated the ISPs to report any content harmful to children to the authorities within 7 days. This Act mentioned individuals, syndicates (Sect. 5) and businesses (Sect. 10) as being liable for punishment for child pornography offences. The Cybercrime Prevention Act of 2012 (Lawphil, 2012) was passed in 2012, which prohibited businesses and computer systems from producing or distributing child pornography materials and made these punishable with heavy fines. The Anti-Photo and Video Voyeurism Act of 2009 prohibited the display of nudity and sexual acts online (Lawphil, 2010). This Act does not specify children, but it could protect children from being indirectly involved in any sexual acts. The Philippines passed the Anti-Bullying Act in 2013, and Sect. 2 of this Act clearly defined the meaning of all forms of bullying, including cyberbullying (Sect. 2.d), while Sect. 3 of this act directed all elementary and secondary schools to adopt policies to address bullying in their respective institutions. Section 4 identified the School Principal as being responsible for the implementation of the Act, and Sect. 5 required schools to periodically report their cyber bullying policies (Lawphil, 2013). The Philippines 
had 12 years as the age of consent, which was the lowest in the region, and The Philippines was long criticised for this low age and in response to this Philippines increased its age of consent from 12 to 16 in 2020 (Mendiola, 2020).

Despite implementing the wide range of legal safeguards to protect children in cyberspace, the Philippines has remained a major destination for child abuse and exploitation. During the COVID-19 pandemic, online sexual abuse of children in the Philippines increased by 264.6 per cent or to 202,605 during the community lockdown from March to May 2020, compared to 76,561 cases reported during the same period in 2019 (Reliefweb, 2021). Problems and delays in law enforcement have long been an issue. For example, in 2009 the United Nations (2009) Committee on the Rights of the Child acknowledged that the natural disasters and armed conflicts in the country had hampered law enforcement from protecting children. This Committee also raised concerns regarding the delays in law enforcement to protect children and that authorities were not capable of taking timely actions to protect children. This Committee noted that the Philippines relied heavily on the participation of child victims to prosecute crimes. This deterred the children from taking part in the legal procedure or children refrained from reporting such crimes to authorities.

\section{Singapore}

Singapore had a population of $5,896,686$, of whom $5,173,907$ people used the Internet, which makes for a high Internet penetration rate of $87.7 \%$ (Internet world stats, 2021). Singapore enacted the Penal Code of Singapore on 1 January 2020, which prohibited the production, distribution, advertisement and possession of child abuse material. This penal code also prohibited sexual grooming (Singapore Legal Advice, 2020). Apart from this, there is Penal code 224 (Sect. 293) which prohibited the sale of obscene materials to children (Singapore Government, 2011), Films Act (Chapter 107), Undesirable Publications Act (Chapter 338) and Children and Young Persons Act (Chapter 38), responsible for the care of children in Singapore. Singapore enacted its law criminalizing cyberbullying and stalking in 2014, which prohibited cyber harassment, bullying of children and other forms of sexual harassment (Palatino, 2014). Despite these proactive legal procedures, Singapore had no law requiring ISPs to report child abuse and child exploitation material to law enforcement agencies if such materials appeared in their network. Due to its proactive approach, Singapore has a good track record of cyber safety for children. It ranked fourth out of 30 countries for having the best online safety for children, according to the Inaugural Child Online Safety Index of the DQ Institute (Yee, 2020).

\section{Thailand}

Thailand had a population of $69,950,850$, of whom $57,000,000$ used the Internet, with a high Internet penetration rate of $81.5 \%$ (Internet world stats, 2021). Thailand amended its Penal Code No. 24 in 2015 to enact new laws on child 
pornography. Section 3/17 of this Act defined the term child pornography, and Sect. 4 of this Act prohibited the possession of child pornography. Offenders possessing child pornography will be imprisoned for up to 5 years, and offenders sharing the pornography will be imprisoned up to 7 years. Importing and distributing child pornography in Thailand incurred a prison term ranging from 3 to 10 years (Wikisource, 2015). Thailand passed the Child Protection Act, B.E. 2546 in 2003 (Government of Thailand, 2003), but this Act did not mention the cyber safety of children. Section 4 of the Anti-Trafficking in Persons Act, B.E. 2551 (2008) (Government of Thailand, 2008) mentioned the production or dissemination of child pornography but did not elaborate further. The Computer Crime Act, B.E.2550 (2007) (Government of Thailand, 2007) prohibited the use of a computer system to disseminate computer data that contained pornographic material but did not specify child pornography. Neither this act or any other in Thailand required ISPs to report child abuse materials to law enforcement agencies or other relevant authorities when they learn of it on their network. Thailand had no laws prohibiting sexual grooming of children and cyberbullying.

While Thailand had many legal frameworks on the cyber safety of children, law enforcement seemed to be weak for many reasons (ECPAT, 2016a, b). Online child sex abuse cases in Thailand hit a record high during the COVID-19 shut down. The Thai police-led Crimes Against Children task force rescued more than 100 children during April and May 2020 — almost double the 53 children rescued in 2018 (Wongsamuth, 2020). Thailand being a country with a high Internet penetration rate of $81.5 \%$, large number of Thai children used the Internet, exposing them to the risk of abuse and exploitation. Thailand's cyber safety laws for children are not commensurate with this increase in children using the Internet.

\section{Vietnam}

Vietnam had a population of $98,168,833$, and within this population $71,540,000$ used the Internet, with an Internet penetration rate of $72.9 \%$ (Internet world stats, 2021). Vietnam revised its penal code in 2015 (Government of Vietnam, 2015). Article 326 of this Code defined child pornography and prohibited the production, sale and distribution of child pornographic material and imposed a high penalty if these materials were distributed through Internet computer networks, telecommunication networks or digital devices. The term child pornography was not clearly defined in the Penal Code 2015, and this may be open to misinterpretation for the wrong purposes. Sexual grooming of children was yet to be prohibited in Vietnam (UNICEF, 2021a, b, c). The Penal Code 2015 hinted at cyberbullying as seriously infringing upon a person's dignity or honour, but there was no legal framework to prohibit cyberbullying of children in Vietnam. Vietnam has taken the leadership in directing ISPs to report any "obscene material" harmful to children passing through their network. However, the term "obscene material" was not clearly defined in the legislation. 


\section{Discussion}

UNICEF (2020) expressed its concern that COVID-19 could severely jeopardise the gains made in reducing child poverty and deprivation in the East Asia and Pacific region over the last 30 years and exacerbate existing inequalities and violations of children's rights (Islam, 2020). The UN (2021) has predicted that the Asia Pacific region will suffer increased levels of unemployment, poverty and food insecurity due to the pandemic and that millions of girls are unlikely to ever return to school and are vulnerable to abuse and exploitation. This concern is very much relevant to the countries in the ASEAN region because COVID-19 has severely affected the economic stability of the region, forcing millions of families into poverty. The ILO and UNICEF have warned that the COVID-19 outbreak could create the first increase in child labour in this region in more than 20 years (ASEAN Post, 2021). Poverty had been the key factor behind child abuse and exploitation in the ASEAN region in the past, and COVID-19 has created a perfect storm. Evidence is emerging that children living in the ASEAN region have already come under increasing pressure to yield to sexual exploitation online (Child Fund Australia, 2021). There is an urgent need for ASEAN countries to take pre-emptive steps to safeguard their children. Strengthening the legal and policy frameworks to facilitate a quick response from law enforcement authorities could be the best way forward for these countries.

The present study, based on a critical analysis of the legal and policy frameworks on the cyber safety of children in the ASEAN region, identified important legal loopholes which need immediate policy attention (Table 1). On a positive note, most countries in the region have taken leadership in addressing the safety of children online and have passed legislations to prevent child abuse and child exploitation in cyberspace. However, the present study revealed some serious inconsistencies in these legislations, which increase the vulnerability of children online. A comparison in relation to the age of consent revealed inconsistencies in the region which have the potential for criminals abusing the legal loopholes. Laos, Myanmar, Malaysia and Thailand were yet to clearly specify the age of consent. Malaysia had a legislation not specifying the age of consent for girls, which exposed girls to sexual exploitation, child marriage and grooming. Myanmar's law specified 14 years as the age of consent, whereas Laos and Thailand had 15 years as the age of consent. Firstly, the age of consent in most of these countries is quite low, and on top of that, there are inconsistencies in age of consent across borders. These inconsistencies in the legislation could be used against the children to force them into child marriages, forced sexual exploitation and abuse. For example, a 41-year-old Malaysian man married an 11-year-old Thai girl, which was legal at the time (The Guardian, 2018). The international standards do not specify the minimum age of consent. However, the CRC Committee has considered 13 years as too early for a child to consent to sexual activity. This Committee was of the view that the actual capacity of a child to make a judgement needed consideration, and at the same time sexual activity between two underage adolescents should not be criminalised (UNICEF, 2021a). Children being forced to get married to partners who are much older than their age is a problem common in the ASEAN region. South Asia has the highest rates of child marriage in 
the world. Almost one in five (17\%) of girls are married before the age of 15 years (UNICEF, 2021b). ASEAN, together with UNICEF, UNFPA and Plan International, reported that $35.4 \%$ of women in Lao PDR, $17 \%$ of women in Indonesia and $11 \%$ of women in Vietnam were married before 18 years of age and the adolescent birth rate in the ASEAN region was 47 births per 1000 females aged 15 to 19 years (ASEAN, 2019). The situation can be changed only if the countries in the region manage to increase the age of consent and criminalise any sexual coercion of children less than 18 years. The inconsistencies in age of consent in the ASEAN region encourage criminals to cross the borders to commit crimes against children, and international tourists groom children in these countries online to sexually exploit them and walk away with no penalty or punishment.

The child cyber safety legislations of Indonesia, Laos, Malaysia, Myanmar, Singapore and Vietnam had inconsistencies in defining the term child pornography, and in some jurisdictions, possession of child pornography alone was not considered an offence. The child cyber safety legislations of Cambodia, Laos, Malaysia, Myanmar and Vietnam did not prohibit an individual from possessing child pornography. This loophole needs immediate attention because these countries may not be able to prosecute someone who possesses child pornography materials and that sends bad signals to the perpetrators of crimes against children. Such inconsistencies in the legislation could promote cross-border criminal activities. The ASEAN region is very well known for cross-border crimes against children in the form of forced prostitution. A vast majority of child sex offenders in Southeast Asia were nationals of the countries of the region. Recent research suggested that Asian men are more likely to sexually abuse young girls and to seek out young virgin girls (ECPAT, 2017).

Cyberbullying is another area that seems to have received policy attention only among six of the ten ASEAN countries. Only the Philippines and Singapore had formulated systematic legislations requiring the schools to implement cyberbullying programs, while the other countries were yet to take formal steps to prevent cyberbullying. Inconsistencies in legislation criminalising the grooming of children for sexual exploitation in the ASEAN region was another major finding of the present study. Except for four countries in the region (Brunei, Malaysia, the Philippines and Singapore), none of the remaining six ASEAN countries had any legislation criminalising sexual grooming. This loophole increases the vulnerability of children in these countries. Sexual grooming in cyberspace could be easily unleashed on a child because the perpetrator need not to be physically present to approach the child. Often, the perpetrators change their identities to contact the child online and harm them. This serious crime had no legal deterrents in Cambodia, Indonesia, Laos, Myanmar, Thailand and Vietnam. Cyber grooming of children for sexual purposes is a transnational problem which requires a transnational solution by all ASEAN countries. Inconsistencies in the legislation create safe havens for child predators, and the ASEAN region is urgently in need of ASEAN communities collaborating with each other. The ASEAN countries may also benefit by forging alliances with business entities such as banks, credit card companies, digital payment systems and other entities to trace child sexual exploiters who use their money power to groom children for sexual purposes (Ward, 2019). 
Internet service providers and content hosts could play an important preventive role by informing the authorities about online material that is harmful to children. This can make cyberspace safe for children. With this in view, many countries in the world have made it mandatory for ISPs to report and remove all illegal and harmful content to prevent children accessing those. Unfortunately, the Philippines was the only country in the ASEAN region that had a legal requirement for the ISPs to report contents that are not appropriate for children. All the remaining countries in the region were yet to take any steps, and it is time that Brunei, Cambodia, Indonesia, Laos, Malaysia, Myanmar, Singapore, Thailand and Vietnam take this matter seriously.

Child abuse and exploitation in cyberspace is a crime that has no geographical borders, which makes it difficult for countries to deal with the problem without international cooperation. Except for Cambodia, the Philippines and Thailand, none of the remaining seven countries in the ASEAN region had any global alliance with

Table 2 Overall suggestions of the study

\begin{tabular}{|c|c|}
\hline Finding of the study & Suggestion \\
\hline $\begin{array}{l}\text { Laos, Myanmar, Malaysia and Thailand were yet } \\
\text { to clearly specify the age of consent }\end{array}$ & $\begin{array}{l}\text { Legislation be passed to declare the age of consent } \\
\text { as } 18 \text { years }\end{array}$ \\
\hline $\begin{array}{l}\text { Malaysia had a legislation not specifying the } \\
\text { age of consent for girls, which exposed girls to } \\
\text { sexual exploitation, child marriage and grooming }\end{array}$ & $\begin{array}{l}\text { Legislation be passed to declare the age of consent } \\
\text { as } 18 \text { years for both males and females }\end{array}$ \\
\hline $\begin{array}{l}\text { Myanmar's law specified } 14 \text { years as the age of } \\
\text { consent }\end{array}$ & $\begin{array}{l}\text { Legislation be passed to declare the age of consent } \\
\text { as } 18 \text { years }\end{array}$ \\
\hline Thailand had 15 years as the age of consent & $\begin{array}{l}\text { Legislation be passed to declare the age of consent } \\
\text { as } 18 \text { years }\end{array}$ \\
\hline $\begin{array}{l}\text { Indonesia, Laos, Malaysia, Myanmar, Singapore } \\
\text { and Vietnam had inconsistencies in defining the } \\
\text { term child pornography }\end{array}$ & $\begin{array}{l}\text { Legal definition of child pornography be specified } \\
\text { in the legislation in line with international stand- } \\
\text { ards along with the punishments }\end{array}$ \\
\hline $\begin{array}{l}\text { Cambodia, Laos, Malaysia, Myanmar and Vietnam } \\
\text { did not prohibit an individual from possessing } \\
\text { child pornography }\end{array}$ & $\begin{array}{l}\text { Legislation be passed to declare possession of child } \\
\text { pornography an offence and clearly avoiding pun- } \\
\text { ishment for possession of child pornography }\end{array}$ \\
\hline $\begin{array}{l}\text { Only Philippines and Singapore had formulated } \\
\text { systematic legislation requiring the schools to } \\
\text { implement cyberbullying programs, whereas the } \\
\text { other countries were yet to take formal steps to } \\
\text { prevent cyberbullying }\end{array}$ & $\begin{array}{l}\text { Countries other than the Philippines in the ASEAN } \\
\text { region should formulate legislation declaring } \\
\text { cyberbullying an offence and direct the schools to } \\
\text { implement cyberbullying awareness creation and } \\
\text { prevention programs }\end{array}$ \\
\hline $\begin{array}{l}\text { Brunei, Malaysia, Philippines and Singapore were } \\
\text { the only countries having legislation criminalis- } \\
\text { ing sexual grooming }\end{array}$ & $\begin{array}{l}\text { Cambodia, Indonesia, Laos, Myanmar, Thailand } \\
\text { and Vietnam should pass legislation criminalising } \\
\text { sexual grooming and clearly legislate the penalty }\end{array}$ \\
\hline $\begin{array}{l}\text { The Philippines was the only country in the } \\
\text { ASEAN region that had a legal requirement for } \\
\text { Internet Service Providers to report contents that } \\
\text { were not appropriate for children }\end{array}$ & $\begin{array}{l}\text { Brunei, Cambodia, Indonesia, Laos, Malaysia, } \\
\text { Myanmar, Singapore, Thailand and Vietnam } \\
\text { should pass legislation directing the Internet } \\
\text { Service Providers to identify contents not suitable } \\
\text { for children and report them to authorities }\end{array}$ \\
\hline $\begin{array}{l}\text { Only Cambodia, the Philippines and Thailand had } \\
\text { global alliances with international law enforce- } \\
\text { ment initiatives }\end{array}$ & $\begin{array}{l}\text { All other countries in the ASEAN region should } \\
\text { establish global alliances with international law } \\
\text { enforcement initiatives }\end{array}$ \\
\hline
\end{tabular}


international law enforcement initiatives (UNICEF, 2015). This might weaken the law enforcement capabilities of these countries, and they could become safe havens for illegal operators to target children for exploitation. Such inconsistency might weaken the ASEAN region, setting off a chain reaction that might harm the other neighbouring countries in the region. ASEAN as an entity should take note of this and ensure that there is consistency in the legal frameworks across borders.

Table 2 presents a summary of the major findings of the study and provides suggestions to improve the legislations to protect the ASEAN children in cyberspace.

\section{Conclusion}

Based on a critical review of the legal and policy frameworks of the ten countries in the ASEAN region, the present research identified major inconsistencies in their child cyber safety laws. Definition of the term child pornography and legal punishment for production, possession and distribution of child pornography is one area that shows serious inconsistencies among ASEAN countries. The study argues that these inconsistencies might result in cross-border crimes which have serious implications for child safety. The present study revealed gross inconsistencies among ASEAN countries in the legal safeguards against grooming children for sexual purposes. Legislations on cyberbullying and obligations of ISPs to report illegal contents in cyberspace to authorities are the other areas where there are loopholes in the legislations of ASEAN countries. Keeping in view these legal loopholes and the significant variations in the legal framework in each ASEAN country, the recommendation is that all ten countries in the region should be signatories to international law enforcement treaties. This will remove the inconsistencies across the countries and will prepare ASEAN countries to work efficiently to reduce cross-border crimes against children in cyberspace. ASEAN as a joint entity has already celebrated five decades of the alliance, and it is time that this entity prepares itself to bring commonality in their legal frameworks to empower their children to benefit from and enjoy the endless potential of cyberspace.

\section{Appendix: Definition of Key Terms Used in the Study}

\section{Child}

According to Article 1 of the United Nations Convention on the Rights of the Child (CRC), a child is anyone below the age of 18 years (United Nations, 1989).

\section{Child/early marriage}

According to the United Nations Convention on the Rights of the Child Article 24 (3), child marriage is the betrothal and the marriage of a child under the age of 18 years. 


\section{Child pornography/child sexual abuse materials}

According to Article 2 (c) of the United Nations' Optional Protocol to the Convention on the Rights of the Child, child pornography means any representation, by whatever means, of a child engaged in real or simulated explicit sexual activities or any representation of the sexual parts of a child for primarily sexual purpose.

\section{Exploitation of children for sexual purposes}

According to the Article 2 (b) of the United Nations' Optional Protocol to the Convention on the Rights of the Child, the exploitation of children in/for prostitution means the use of a child in sexual activities for remuneration or any other form of consideration.

\section{Grooming (online/offline) for sexual purposes}

"Grooming" is the short name for the solicitation of children for sexual purposes. Grooming/online grooming refers to the process of establishing/building a relationship with a child either in person or through the use of the Internet or other digital technologies to facilitate either online or offline sexual contact with that person.

\section{Online child sexual abuse}

According to ILO C 182 - Article 3 (b), online child sexual abuse means the use, procuring or offering of a child for prostitution, for the production of pornography or for pornographic performances.

\section{Sexual exploitation of children}

According to the CRC - Article 34, sexual exploitation of children means the exploitative use of children in prostitution or other unlawful sexual practices.

\section{Declarations}

Conflict of interest The author declares no competing interests.

\section{References}

Abdullah, S. C., \& Metussin, H. (2016). Assessing online interaction of Bruneian children. CSPS Strategy and Policy Journal, 6, 67-85. 
Beh, L., \& Lin, W. L. (2021). Impact of COVID-19 on ASEAN tourism industry. Journal of Asian Public Policy. https://doi.org/10.1080/17516234.2020.1871180

Wismayanti, Y. F., O’Leary, P., Tilbury, C., \& Tjoe, Y. (2019). Child sexual abuse in Indonesia: A systematic revi. Child abuse and neglect, 95(2019), 104034. https://doi.org/10.1016/j.chiabu.2019. 104034

Ammon, R., (2019). Cambodia-sex and politics. Retrieved May 1, 2021, from https://www.globalgayz. com/cambodia-sex-and-politics/342/\#: :text=\%3DThe $\% 20 U N \% 20$ Convention $\% 20$ on $\% 20$ the, is $\%$ 20not\%20illegal\%20in\%20Cambodia

Arliman, L., Situngkir, D. A., Hariyadi, Putri, R. R., et al., (2018). Cyber bullying against children in Indonesia. Retrieved May 2, 2021, from https://eudl.eu/pdf/10.4108/eai.5-9-2018.2281372

ASEAN (2019). ASEAN calls for ending child, early and forced marriage, Retrieved July 2, 2021, from https://asean.org/asean-calls-ending-child-early-forced-marriage/.

ASEAN (2021). Invest in ASEAN. Retrieved May 2, 2021, from the Association of Southeast Asian Nations, http://investasean.asean.org/index.php/page/view/about-the-asean-region/view/707/newsid/ 930/diverse-asean.html.

ASEAN Post (2021). The impact of COVID-19 on child labour. Retrieved May 3, 2021, from https:// theaseanpost.com/article/impacts-covid-19-child-labour.

Mubarak, A. R. (2015). Child Safety Issues in Cyberspace: A Critical Theory of Trends and Challenges in the ASEAN Region. International Journal of Computer Applications, 129(1), 48-55. http://www. ijcaonline.org/archives/volume129/number1/23041-2015906925.

BBC (2016). Indonesia passes chemical castration law for paedophiles. Retrieved May 2, 2021, from https://www.bbc.com/news/world-asia-37629558.

Blomberg, M., (2019). Cambodia feared lagging behind predators in cybersex trafficking crackdown. Retrieved May 1, 2021, from https://www.reuters.com/article/us-cambodia-sexcrimes-childrenidUSKCN1VW00B

Brewster, T., (2021). Online child abuse complaints surpass 4 million in April. This is how cops are coping despite COVID-19. Retrieved April 24, 2021, from https://www.forbes.com/sites/thomasbrew ster/2020/05/09/online-child-abuse-complaints-surpass-4-million-in-april-this-is-how-cops-are-coping-despite-covid-19/?sh=488fc8e048db

Brunei Attorney General's Chamber (2001). Penal Code, Laws of Brunei, Chapter 22, Revised Edition, 2001. Retrieved May 2, 2021, from http://www.agc.gov.bn/AGC\%20Images/LOB/PDF/Cap22.pdf

Brunei Attorney General's Chamber (2016). The Penal Code Amendment Order 2016. Retrieved May 2, 2021, from http://www.agc.gov.bn/AGC\%20Images/LAWS/ACT_PDF/Cap.22a.pdf

Brunei Government (2006). Supplement to government gazette part II, Brunei Government. Retrieved May 2, 2021, from http://www.bruneiresources.com/pdf/gazette_06_2006.pdf

Business and Human Rights (2021). Cambodia: Child protection unit creates an online group to combat any form of child sexual exploitation and abuse. Retrieved May 2, 2021, from https://www.businesshumanrights.org/en/latest-news/cambodia-child-protection-unit-creates-an-online-group-to-combatany-form-of-child-sexual-exploitation-and-abuse/

Cambodian Centre for Human Rights (2021). Digital rights project. Retrieved May 1, 2021, from https:// cchrcambodia.org/index_old.php?url=project_page/project_page.php\&p=project_profile.php\&id= $3 \&$ pro=DR\&pro_id $=102 \&$ show $=$ show

Chatterji, R., (2021). China's relationship with ASEAN: An explainer, ORF Issue Brief No. 459, April 2021, Retrieved July 2, 2021, from Observer Research Foundation, https://www.orfonline.org/resea $\mathrm{rch} /$ china-relationship-asean-explainer/

Child Fund Australia (2021). Covid-19 the perfect storm for online child exploitation. Retrieved May 3, 2021, from https://www.childfund.org.au/stories/covid-19-the-perfect-storm-for-online-exploitation/

Cuddy, A., (2021). Myanmar Coup: What is happening and why? BBC News, Retrieved July 2, 2021, from https://www.bbc.com/news/world-asia-55902070

Doyle, K., (2014). Vietnam's forgotten Cambodian war, BBC News, Retrieved July 2, 2021, from https:// www.bbc.com/news/world-asia-29106034

ECPAT (2016a). Regional report on sexual exploitation of children in travel and tourism, Retrieved July 2, 2021, from https://www.ecpat.org/what-we-do/sexual-exploitation-of-children-travel-tourism/

ECPAT (2016b). Executive summary - Thailand, Retrieved May 3, 2021, from https://www.ecpat.org/ wp-content/uploads/2016/04/exsum_a4a_eap_thailand.pdf

ECPAT (2017). The sexual exploitation of children in Southeast Asia. Retrieved September 21, from https://www.ecpat.org/wpcontent/uploads/2021/05/Regional-Overview_Southeast-Asia.pdf 
ECPAT (2019). Malaysia - What we know about the sexual exploitation of children in the country. Retrieved May 2, 2021, from https://www.ecpat.org/news/malaysia-sexual-exploitation/

ECPAT (2020). Sexual exploitation of children in Myanmar submission for the universal periodic review of the Human Rights situation in Myanmar. Retrieved May 2, 2021, from file://uniwa. uwa.edu.au/userhome/staff4/00103264/Downloads/ECPAT\%20International_UPR37_MMR_E_ Main.pdf

ECPAT (2021). Summary - Laos. Retrieved May 2, 2021, from https://www.ecpat.org/wp-content/ uploads/2017/05/Ex_Summary_LAOS-PDR.pdf

Google, Temasek \& Bain \& Company (2019). e-conomy SEA 2019 Swipe up and to the right: Southeast Asia's $\$ 100$ billion internet economy. Retrieved September 21, from http://think.storage. googleapis.com/docs/e-Conomy_SEA_2019_report.pdf

Government of Laos (2006) Law on the protection of the rights and interests of children. Retrieved May 2, 2021, from https://www.vientianetimes.org.la/Laws\%20in\%20English/65.\%20Law\% 20on\%20the \%20Protection\%20of\%20the\%20Rights\%20of\%20Children\%20(2006)\%20Eng.pdf

Government of Malaysia (2017). Sexual offences against children act 2017. Retrieved May 2, 2021, from http://www.foongchengleong.com/downloads/Sexual\%20Offences\%20Against\%20Chi ldren\%20Act\%202017.pdf

Government of Thailand (2003). Child protection act 2003. Retrieved May 3, 2021, from http://web. krisdika.go.th/data/outsitedata/outsite21/file/CHILD_PROTECTION_ACT_B.E._2546.pdf

Government of Thailand (2007). Computer-related crime act, 2007. Retrieved May 3, 2021, from file://uniwa.uwa.edu.au/userhome/staff4/00103264/Downloads/Law_ECOM_32_EN.pdf

Government of Thailand (2008). Anti-human trafficking act, 2008. Retrieved May 3, 2021, from http:// web.krisdika.go.th/data/outsitedata/outsite21/file/ANTI_HUMAN_TRAFFICKING_ACT,B.E._ 2551_(2008).pdf

Government of Viet Nam (2015). Criminal code 2015. Retrieved May 3, 2021, from https://www. wipo.int/edocs/lexdocs/laws/en/vn/vn086en.pdf

HAKAM (2019). Malaysia tops in South-East Asia for online child pornography. Retrieved May 2 , 2021, from https://hakam.org.my/wp/tag/child-pornography/

International Centre for Missing and Exploited Children (2017). Indonesia - National child protection legislation. Retrieved May 2, 2021, from https:/www.icmec.org/wp-content/uploads/2017/ 08/Indonesia-National-Legislation.pdf

International Labour Organisation (2007). Cambodia - Criminal and penal law. Retrieved May 2, 2021, from Elimination of child labour, protection of children and young persons, http://www. ilo.org/dyn/natlex/natlex4.detail?p_lang=en\&p_isn=93355

Internet World Stats (2021). Internet world stats - Usage and population statistics. Retrieved September 21, from https://www.internetworldstats.com/stats.htm

INTERPOL (2021). Behaviour of both offenders and victims affected by measures to contain the pandemic. Retrieved April 26, 2021, from https://www.interpol.int/en/News-and-Events/News/2020/ INTERPOL-report-highlights-impact-of-COVID-19-on-child-sexual-abuse

Islam, S., (2020). Keep the well-being of children of East Asia and Pacific at the centre of COVID-19 response and recovery. Retrieved May 3, 2021, from https://violenceagainstchildren.un.org/zh/ node/3609

Izzuddin, M., (2020). India has left RCEP behind but not its ambitions in Southeast Asia, Lowy Institute, Retrieved July 2, 2021, from https://www.lowyinstitute.org/the-interpreter/india-has-leftrcep-behind-not-its-ambition-southeast-asia

Khairunnisa, S., Siregar, A.B.R., \& Tanjung, A.S., (2013). Law on cyberbullying in Indonesia, Malaysia and Brunei Darussalam, Proceedings of the $2^{\text {nd }}$ international conference on multidisciplinary research, October 2-4, 2013, Banda Aceh, Indonesia. Retrieved May 1, 2021, from file://uniwa. uwa.edu.au/userhome/staff4/00103264/Downloads/269-133-526-1-10-20181003\%20(2).pdf

Lawphil (2009). Republic Act No. 9775 Anti-child pornography act of 2009. Retrieved May 2, 2021, from https://lawphil.net/statutes/repacts/ra2009/ra_9775_2009.html

Lawphil (2010). Anti-photo and video voyeurism act of 2009. Retrieved May 2, 2021, from https:// lawphil.net/statutes/repacts/ra2010/ra_9995_2010.html

Lawphil (2012). Cybercrime prevention act of 2012. Retrieved May 2, 2021, from https://lawphil.net/ statutes/repacts/ra2012/ra_10175_2012.html

Lawphil (2013). Anti-bullying act of 2013. Retrieved May 2, 2021, from https://lawphil.net/statutes/ repacts/ra2013/ra_10627_2013.html 
Lee, K., (2021). The \#MilkTeaAlliance in Southeast Asia: Digital revolution and repression in Myanmar and Thailand, Centre for strategic and international studies. Retrieved April 18, 2021, from https:// www.csis.org/blogs/new-perspectives-asia/milkteaalliance-southeast-asia-digital-revolution-andrepression-myanmar

Leong, D., (2020). Commentary: The Milk Tea alliance sweeping through Thailand is a force to be reckoned with, Channel News Asia. Retrieved April 18, 2021, from https://www.channelnewsasia.com/ news/commentary/milk-tea-alliance-thailand-hong-kong-taiwan-protest-prayut-china-13534668

Mendiola, R., (2020). Philippines to raise age of consent from 12 to 16. Retrieved May 2, 2021, from https://www.asianjournal.com/philippines/across-the-islands/ph-to-raise-age-of-conse nt-from-12-to-16/

Mubarak, A. R., (2015). Child safety issues in cyberspace: A critical theory of trends and challenges in the ASEAN Region. International Journal of Computer Applications, 129(1), 48-55. http://www. ijcaonline.org/archives/volume129/number1/23041-2015906925

Palatino, M., (2014). Singapore criminalizes cyber bullying and stalking. Retrieved May 2, 2021, from https://thediplomat.com/2014/03/singapore-criminalizes-cyber-bullying-and-stalking/

Phonevilay, L., (2020). Laos establishes mechanism for cyberbullying complaints, The Laotian times. Retrieved May 2, 2021, from https://laotiantimes.com/2020/09/09/laos-establishes-mechanism-forcyberbullying-complaints/

Reliefweb (2021). Online sexual abuse of children rising amid COVID-19 pandemic - Save the children Philippines. Retrieved 2 May, 2021. From https://reliefweb.int/report/philippines/online-sexualabuse-children-rising-amid-covid-19-pandemic-save-children

Reuters (2021). Southeast Asia's internet economy to cross $\$ 100$ billion this year: Industry report. Retrieved April 18, 2021, from https://www.reuters.com/article/us-southeast-asia-technologyidUSKBN27Q0CB.

Singapore Government (2011). Penal code chapter 224. Retrieved May 2, 2021, from https://www.icj. org/wp-content/uploads/1972/09/Singapore-Penal-Code-1872-2011-eng.pdf

Singapore Legal Advice (2020). Child pornography in Singapore: Offences and penalties. Retrieved May2, 2021, from https://singaporelegaladvice.com/law-articles/child-pornography-singapore-offen ces-penalties/\#involving

Statista (2019). ASEAN: Tourist arrivals from ASEAN countries 2019, Retrieved July 2, 2021, from https://www.statista.com/statistics/645761/tourist-arrivals-in-asean-region-from-other-asean-count ries/

Statista (2021). Internet penetration in Southeast Asia as of December 2020, by country. Retrieved April 18, 2021, from https://www.statista.com/statistics/487965/internet-penetration-in-southeast-asiancountries/

Sullivan, M., (2020). Child sex abuse livestreams increase during Coronavirus lockdowns. Retrieved May 1, 2021, from https://www.npr.org/sections/coronavirus-live-updates/2020/04/08/828827926/ child-sex-abuse-livestreams-increase-during-coronavirus-lockdowns

The ASEAN post (2021). Cambodia's cyberbullied children. Retrieved May 1, 2021, from https://theas eanpost.com/article/cambodias-cyberbullied-children

The Guardian (2018). Outrage after Malaysian man marries 11-year-old Thai girl, Retrieved July 4, 2021, from https://www.theguardian.com/world/2018/jul/01/outrage-after-malaysian-man-marri es-11-year-old-thai-girl

UNICEF (2015). Child protection in the digital age - National responses to online child sexual abuse and exploitation in ASEAN. Retrieved May 4, 2020, from https://www.unicef.org/eap/reports/childprotection-digital-age

UNICEF (2019). Working together for better online child protection. Retrieved May 2, 2021, from https:// www.unicef.org/malaysia/press-releases/working-together-better-online-child-protection

UNICEF (2021a). Child sexual abuse - Recommended reforms. Retrieved May 3, 2021, from https:// www.unicef.org/vietnam/media/3396/file/Child\%20Sexual\%20Abuse\%20recommended\%20ref orms.pdf

UNICEF (2021b). It is time to reopen Southeast Asia's schools - Pandemic reveals weaknesses in education but also ways to improve it. Retrieve April 18, 2021, from https://www.unicef.org/eap/it-timereopen-southeast-asias-schools

UNICEF (2021). Legal minimum ages and the realization of adolescents' rights. Retrieved July 2, 2021, from https://www.unicef.org/lac/en/reports/legal-minimun-ages

UNICEF (2021). Child marriage, UNICEF, Retrieved July 2, 2021, from https://www.unicef.org/prote ction/child-marriage 
United Nations (2009) Committee on the rights of the child. Retrieved May 2, 2021, from https://www2. ohchr.org/english/bodies/crc/docs/co/CRC-C-PHL-CO4.pdf

United Nations (2021). South Asia: Sharp rise in child and maternal deaths due to COVID-19. Retrieved May 3, 2021, from https://news.un.org/en/story/2021/03/1087542

United Nations Population Fund (2021). Addressing the needs of young people and promoting their potential. Retrieved May 2, 2021, from https://indonesia.unfpa.org/en/topics/adolescent-pregnancy1\#: :text=Indonesia's\%2065\%20million\%20young\%20people,comprise $\% 2028 \% 25 \% 20$ of $\% 20$ the \% 20population

Ushama, K. N. M., \& Jalil, J. A., (2020). Malaysia's legal response to tackling the crime of online child pornography, Law Journal 28 (1): IIUM law journal

Ward, O. (2019). The dark side of technology: ASEAN's vulnerable children, ASEAN Today. Retrieved July 2, 2021, from https://www.aseantoday.com/2019/05/the-dark-side-of-technology-aseans-vulne rable-children/

Wikisource (2015). Translation: Act amending penal code (No.24), 2558 BE. Retrieved May 3, 2021, from https://en.wikisource.org/wiki/Translation:Act_Amending_the_Penal_Code_(No._24),_2558_ $\mathrm{BE}$

Wongsamuth, N., (2020). Online child sex abuse in nears record high with coronavirus. Retrieved May 3 , 2021, from https:/www.ecpat.org/wp-content/uploads/2016/04/exsum_a4a_eap_thailand.pdf

World Bank (2021). COVID-19 (Coronavirus) Response, The World Bank IBRD-IDA. Retrieved May 1, 2021, from https://www.worldbank.org/en/region/eap/coronavirus

Xiang, Y.W., (2020). Malaysia ranks $2^{\text {nd }}$ in Asia for cyberbullying among youth. Retrieved May 2, 2021, from https://says.com/my/news/malaysia-ranks-2nd-in-asia-for-cyberbullying-among-children

Xinhuanet (2019). UNICEF calls for action to prevent bullying, harassment for young people online in Cambodia. Retrieved May 1, 2021, from, http://www.xinhuanet.com/english/2019-02/05/c_13780 0878.htm

Xinhuanet (2021). Cambodia launches online child protection campaign. Retrieved May 1, 2021, from http://www.xinhuanet.com/english/2021-03/10/c_139800018.htm

Yee, Y.W., (2020). Singapore ranks $4^{\text {th }}$ for best online safety for children: Survey. Retrieved May 2, 2021, from https://www.straitstimes.com/tech/singapore-ranks-4th-for-best-online-safety-for-child ren-survey

Yi, B.H., (2021). Australia's coronavirus outbreak raises alarm over online child sex abuse. Retrieved April 26, 2021, from https://www.reuters.com/article/us-australia-technology-crime-trfn-idUSK CN24M1JM

Publisher's Note Springer Nature remains neutral with regard to jurisdictional claims in published maps and institutional affiliations. 